УДК 499.86.676.034

I.O. ДУДЛА

ДЗ Луганський національний університет імені Тараса Шевченка

Г.І. ГОЛОДЮК, Н.М. ГУРГУЛА

Луиький національний технічний університет

\title{
ДОСЛІДЖЕННЯ ТЕПЛОІЗОЛЯЦІЙНИХ МАТЕРІАЛІВ НА ОСНОВІ РОСЛИННОЇ СИРОВИНИ НА МІЦНІСТЬ
}

\author{
I. DUDLA \\ DZ Luhansk Taras Shevchenko National University \\ G. GOLODYUK, N. GURGULA \\ Lutsk national technical university
}

\section{RESEARCH OF THERMAL INSULATION MATERIAL ON THE BASIS OF VEGETABLE RAW MATERIALS FOR STRENGTH}

\section{https://doi.org/10.36910/6775-2310-5283-2022-15-16}

Мета. Пошук і створення ефективних теплоізоляційних матеріалів на основі рослинної сировини та отримання пластинчастого теплоізолячійного матеріалу 3 високими фізико-механічними властивостями, щуо має біоцидні властивості, на основі природного рослинного матеріалу та відходів рослинництва.

Методика. Основні фізико-механічні властивості теплоізоляційних плит щзільність, міцність на стиск при 10\% деформації були визначені відповідно до ДСТУ Б B.2.7-38-95 «Матеріали і вироби теплоізолячійні. Методи випробувань».

Результат. Випробування на міцність при 10\% деформації проводили на зразках теплоізоляційних матеріалів розміром $100 \times 100 \times 100$ мм, змінюючи компоненти та кількість заповнювача. Отримані дані дозволяють встановити, щзо для всіх композицій міцність зразків із суміші моху та соломи більша, ніж для зразків моху та очерету.

На зразках-кубах із сумімі моху та очерету зафіксовані ті самі недоліки, щзо й у плит на однокомпонентному заповнювачі: пухка моховидна волокниста структура, відсутність когерентної маси очерету, деформації усадки після сушіння.

Слід також зазначити, щзо при однаковій кількості в'яжучого, збільшення кількості подрібненого очерету або соломи в загальній масі заповнювача призводить до збільшення міџності зразків, а також встановили, щу для всіх композицій міџність зразків із суміші моху та соломи більша, ніж для зразків моху та очерету. Збільшення витрати заповнювача та рідкого скла натрію призводить до збільшення щуільності ізолячійних матеріалів, щзо містять мох, у 1,3 - 1,4 рази, збільшення міџності на стиск при 10\% 
деформаиії в 1,9 - 4,2 рази. 3 метою усунення недоліків, властивих матеріалу, на однокомпонентному заповнювачі вводили очеретяну звичайну або житню солому. Наявність соломи в композииії з мохом збільшуе міцність при 10\% деформації в 1,5-3 рази, міџність на вигин у 2-3,2 і дозволяє усунути деформаџії усадки з незначним збільшенням коефімієнта теплопровідності.

Наукова новизна. Отримання пластинчастого теплоізоляційного матеріалу 3 високими фізико-механічними властивостями, щзо володіє біоцидними властивостями на основі природного рослинного матеріалу та відходів рослинництва.

Практична значимість. Пошук $i$ створення ефективних теплоізоляційних матеріалів на основі дешевої сировини продовжує залишатися викликом. При иьому велике значення має критерій економї паливно-енергетичних ресурсів при виробництві теплоізолячійних матеріалів. Залежно від складу речовин, 3 яких виготовлені теплоізоляційні матеріали, вони за певних умов можуть впливати на утеплені поверхні, навколишнє середовище та організм людини чи тварини.

Ключові слова: ізоляція, мох, міџність, сировина, сільськогосподарські відходи, очерет солома.

Постановка проблеми у загальному вигляді і її зв'язок з важливими науковими та практичними завданнями. Для опису поточної ситуації у світовій галузі теплоізоляції було проведено огляд літератури існуючих екологічно чистих ізоляційних матеріалів на основі природної сировини 3 різними виготовленими формами та властивостями. Все більшого поширення набувають сучасні екологічно чисті утеплювачі 3 рослинної сировини. Найчастіше ці матеріали виготовляються 3 волокон льону, конопель або дерева, скріплених безпечними в'яжучими компонентами. Натуральні утеплювачі виготовляються у вигляді матів, плит i рулонів, що робить матеріал універсальним з точки зору варіантів нанесення.

Пошук і створення ефективних теплоізоляційних матеріалів на основі дешевої сировини продовжує залишатися викликом. При цьому велике значення мають критерій економії паливно-енергетичних ресурсів при виробництві теплоізоляційних матеріалів. Залежно від складу речовин, з яких виготовлені теплоізоляційні матеріали, вони за певних умов можуть впливати на утеплені поверхні, навколишнє середовище та організм людини чи тварини. У подальших дослідженнях пропонується пошук рішень для підвищення міцнісних властивостей отриманого матеріалу плити без втрати теплоізоляційних властивостей.

Аналіз останніх досліджень та публікацій, у яких започатковано вирішення проблеми. За останні роки вченими Л. Дядюша, Ю. Бобровим, 
В. Граневим, В. Курдюмовою, Н. Гончаровим, А. Люсевим велика увага приділялась широкому використанню відходів промисловості і сільського господарства в виробництві теплоізоляційних матеріалів. О. Лівінський, О. Пшінько, М. Савицький, Ю. Бобров, Е. Овчаренко, Б. Шойхет, Е. Петухова у своїх роботах подали інформацію про стан виробництва, класифікацію, будову, властивості основних теплоізоляційних матеріалів $\mathrm{i}$ конструкцій, а також області їх раціонального застосування.

Цілі статті. Пошук і створення ефективних теплоізоляційних матеріалів на основі рослинної сировини.

Об’єкт дослідження. Теплоізоляційні матеріали на основі рослинної сировини природного походження сільськогосподарського виробництва.

Методи дослідження. У ході проведення дослідження використано аналітичні та систематичні методи обробки даних. Основні фізико-механічні властивості теплоізоляційних плит - щільність, міцність на стиск при $10 \%$ деформації були визначені відповідно до ДСТУ Б В.2.7-38-95 «Матеріали і вироби теплоізоляційні. Методи випробувань [2]».

Випробування на міцність при 10\% деформації проводили на зразках розміром з кубики $100 \times 100 \times 100$ мм. Зразки витримували у формах протягом 5-6 годин з подальшим висушуванням протягом 6-7 годин.

Виклад основного матеріалу дослідження 3 обгрунтуванням отриманих наукових результатів. Випробування на міцність при $10 \%$ деформації проводили на зразках розміром з кубики $100 \times 100 \times 100$ мм. Зразки витримували у формах протягом 5-6 годин 3 подальшим висушуванням протягом 6-7 годин.

Аналіз отриманих даних показав, що збільшення кількості заповнювача збільшує міцність матеріалу при $10 \%$ деформації. Наприклад, у композиціях 1 (витрата компонентів, г - мох 140, рідке скло 220) і 4 (витрата компонентів, г - мох 80, рідке скло 220) з рівною кількістю сполучного, збільшення витрати заповнювача збільшує міцність матеріалу при $10 \%$ деформації в 1,9 рази від 0,11 МПа до 0,21 МПа. Подібна залежність спостерігається при зміні споживання сполучного. Таким чином, при рівній кількості заповнювача 120 г (композиції 2 витрати рідкого скла -220 г і 10 витрати рідкого скла - 100 г), при збільшенні витрати рідкого скла на 120 г, міцність композиції 2 збільшується в 2 рази. Відповідно до встановлених залежностей (рис. 1), збільшення сукупного споживання забезпечує збільшення міцності на 0,070,1 МПа при фіксованій кількості в'яжучого. Зміна витрати в'яжучого від 100 
до 220 г збільшує показник міцності на 0,06-0,09 МПа на зразках з однаковим споживанням моху.

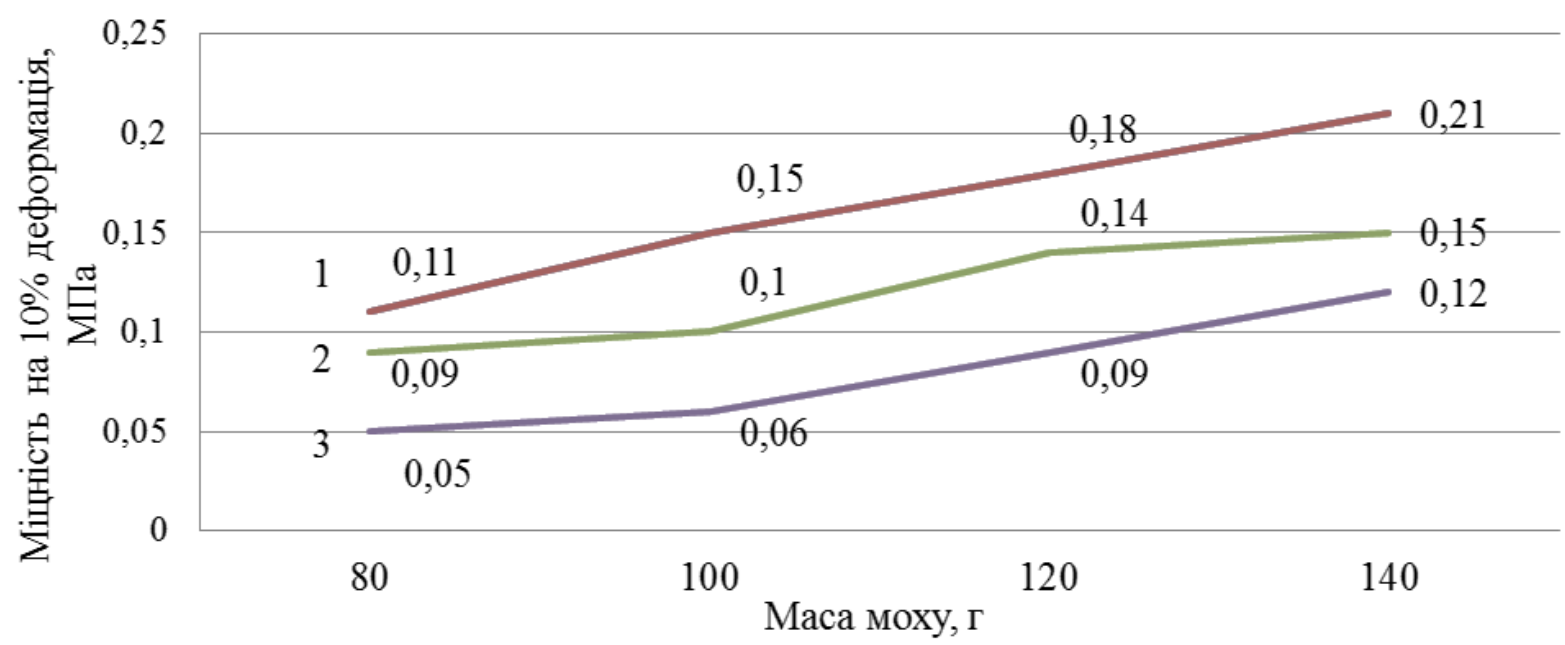

1 - композичії (1-4 витрата рідкого скла 400 г); 2 - композищії (5-8 витрата рідкого скла 300 г);3 - композииії (9-12 витрата рідкого скла 200 )г

Рис. 1. Залежність зміни міцності зразків при 10\% деформації від маси Moxy

На другому етапі досліджень зразки готували на основі компонентів із сумішей моху та очерету, а також моху та соломи (рис. 2).

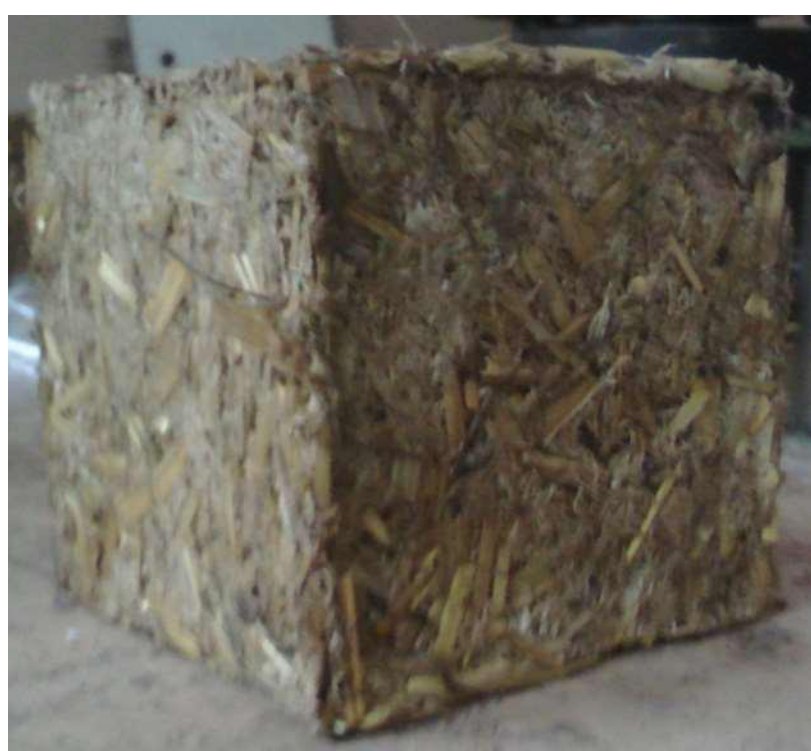

Рис.2. Загальний вигляд зразка-куба на основі моху та соломи 
Аналіз результатів досліджень при заміні частини моху очеретом або соломою у складі заповнювача показав збільшення міцності при $10 \%$ деформації порівняно із зразками на однокомпонентному заповнювачі. Так, міцність при 10\% деформації композиції 1(мох: солома - 50:50 коефіцієнт, \%, рідке скло - 220 г) на основі моху та соломи становить 0,32 МПа, що на 52\% вище, ніж однокомпонентної композиції 1 (Витрата компонентів, г. мох - 140 рідке скло - 220 г). Найбільша міцність кубів зразків на двокомпонентному заповнювачі із суміші моху та очерету становить 0,27 МПа (склад 1 коефіцієнт,\% мох:очерету 50:50, рідке скло - 220 г), що на 29\% вище однокомпонентного складу та на 19\% нижче значення складу 1 (витрата компонентів, г - мох - 140 рідке скло - 220 г).

Слід також зазначити, що при однаковій кількості в'яжучого, збільшення кількості подрібненого очерету або соломи в загальній масі заповнювача призводить до збільшення міцності зразків (рис. 3, рис. 4).

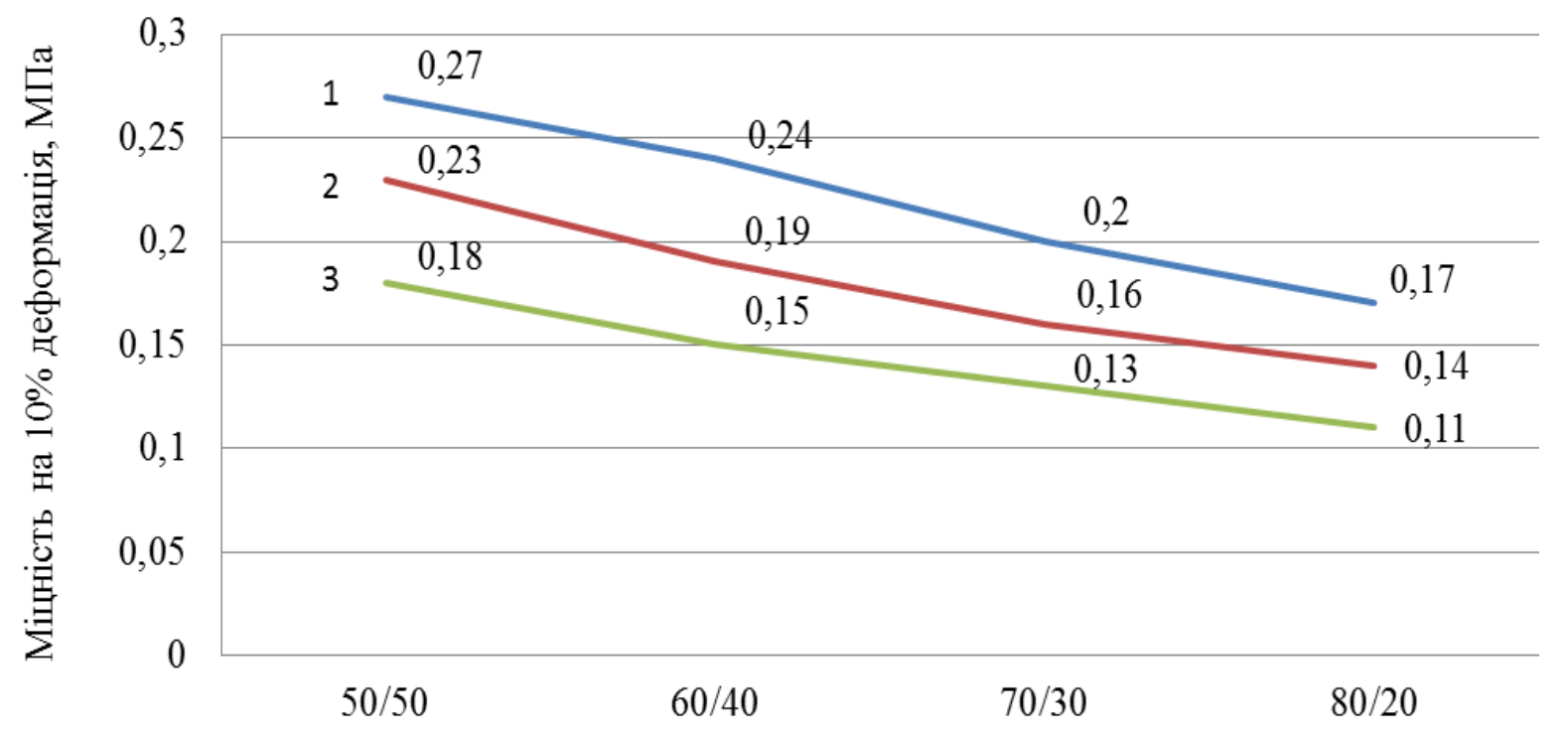

мох: очерет коефіцієнт, \%

1 - композииії (1-4 витрата рідкого скла 400 г); 2 - композиції (5-8 витрата рідкого скла 300 г); 3 - композииії (9-12 витрата рідкого скла 200 г)

\section{Рис. 3. Залежність зміни міцності зразків при 10\% деформації від} співвідношення моху та очерету в суміші заповнювачів 
При порівнянні композицій 8 (коефіцієнт, \% мох: солома 80:20, рідке скло 160 г) та 7 (коефіцієнт, \% мох: солома 70:30, рідке скло 160 г) на основі моху та соломи спостерігається збільшення показника міцності на 0,03 МПа. При подальшому збільшенні частки соломи в сукупності показник міцності збільшується на $41 \%$.

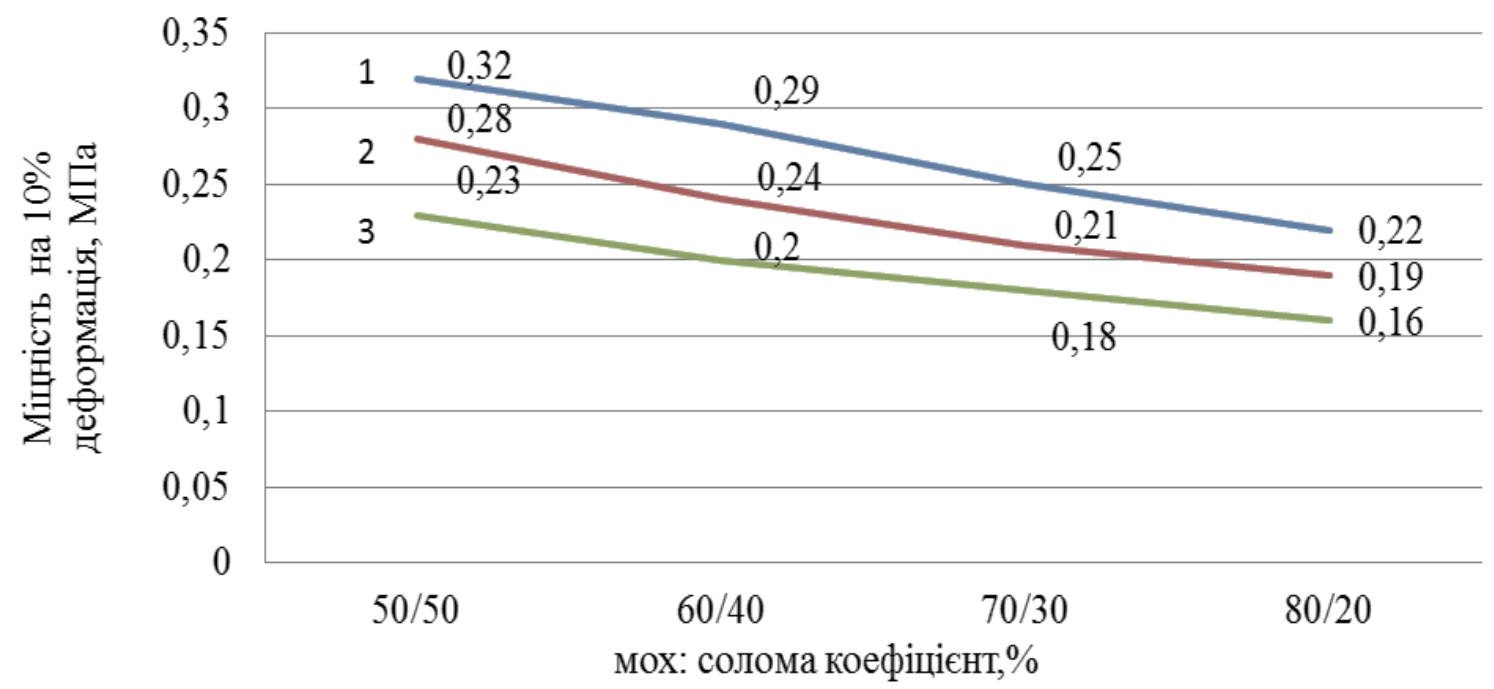

1 - композичії (1-4 витрата рідкого скла 400 г); 2 - композиції (5-8 витрата рідкого скла 300 г); 3 - композиції (9-12 витрата рідкого скла 200 г)

\section{Рис. 4. Залежність зміни міцності зразків при 10\% деформації від співвідношення моху та соломи в суміші заповнювачів}

Подібна залежність спостерігається при збільшенні витрати в'яжучого при однаковій кількості та співвідношенні компонентів наповнювача в складі суміші. При порівнянні композицій 10 (60:40, рідке скло - 100 г) та 2 (60:40, рідке скло -220 г) на основі моху та очерету показник міцності збільшується на 40\% $з$ 0,15 МПа до 0,21 МПа відповідно.

Висновки та перспективи подальших досліджень. Отримані дані дозволяють встановити, що для всіх композицій міцність зразків із суміші моху та соломи більша, ніж для зразків моху та очерету. Наприклад, коли міцність композиції 3 (мох: солома -70:30 коефіцієнт,\%) дорівнює 0,25 МПа, а композиція 3 (мох: очерет- 70:30 коефіцієнт,\%) порівнюється з 0,2 МПа при $0,2 \%$, спостерігається збільшення на $25 \%$. Твердий когерентний структурований каркас, створений подрібненою соломою, призначений не 
тільки для усунення усадочних деформацій, але і для поглинання зовнішніх навантажень, чому сприяє форма частинок соломи, що зберігаються у вигляді пустотілих балонів, збережених після пресування зразків. Таким чином, пояснюється більша міцність при 10\% деформації, отримана 3 матеріалів на двокомпонентному заповнювачі моху та соломи.

Слід зазначити, що на зразках-кубах із суміші моху та очерету зафіксовані ті самі недоліки, що й у плит на однокомпонентному заповнювачі: пухка моховидна волокниста структура, відсутність когерентної туші очерету, деформації усадки після сушіння. Менший об'єм очерету порівняно з соломою при однаковій масі, руйнування тростинних труб під час формування, менш щільна структура зразків та відсутність когерентного каркасу є факторами, що обумовлюють меншу міцність щодо матеріалу від суміш моху та соломи. У зразках із суміші моху та соломи ці негативні фактори відсутні, що в результаті дозволяє досягнути більш високих характеристик міцності. Збільшення витрати заповнювача та рідкого скла натрію призводить до збільшення щільності ізоляційних матеріалів, що містять мох, у 1,3 - 1,4 рази, збільшення міцності на стиск при 10\% деформації в 1,9 - 4,2 рази. 3 метою усунення недоліків, властивих матеріалу, на однокомпонентному заповнювачі вводили очеретяну звичайну або житню солому. Наявність соломи в композиції з мохом збільшує міцність при $10 \%$ деформації в 1,5-3 рази, міцність на вигин у 2-3,2 і дозволяє усунути деформації усадки з незначним збільшенням коефіцієнта теплопровідності.

\section{Список використаних джерел}

1. Будівельні матеріали та вироби / О.М. Лівінський та ін. Дніпропетровськ : Акцент ПП, 2014. $658 \mathrm{c}$.

2. ДСТУ Б В.2.7-38-95 (ГОСТ 17171-94). 01.09.1996. Матеріали i вироби теплоізоляційні. Методи випробувань. [Чинний від 1996-09-01]. Київ, 1996. 25 с. (Національні стандарти України).

3. Пушкарьова К.К. Сучасні українські будівельні матеріали, вироби та конструкції : Асоціація «ВСВБМВ», 2012. 664 с.

4. Якісна теплоізоляція. Принципи інтегрованого термічного захисту. Passive HouseIGUA Українська ініціативна група Пасивного Будинку : веб-сай. URL: http://passivehouseigua.com/passivehouse/passive-house-integrated-thermal-protection (дата звернення: 08.12.2021).

\section{Reference}

1. Livinskyi, O.M., Pshinko, O.M., Savytskyi, M.V.,Kulichenko, I.I., Kurok, O.I., Dorofieiev, V.S. et al. (2014). Budivelni materialy ta vyroby [Building materials and products]. Dnipropetrovsk : Aktsent PP. [in Ukrainian]. 
2. Materialy i vyroby teploizoliatsiini. Metody vyprobuvan [Heat-insulating materials and products. Test methods]. (1995). DSTU B V.2.7-38-95 (HOST 17171-94). from 9th September 1995. Kyiv: Natsionalni standarty Ukrainy [in Ukrainian].

3. Pushkarova K.K. (2012). Suchasni ukrainski budivelni materialy, vyroby ta konstruktsii [Modern Ukrainian bu ilding materials, products and structures]. Asotsiatsiia «VSVBMV». [in Ukrainian].

4. Iakisna teploizoliatsiia. Pryntsypy intehrovanoho termichnoho zakhystu. [Highquality thermal insulation. Principles of integrated thermal protection.]. Passive House-IGUA Ukrainska initsiatyvna hrupa Pasyvnoho Budynku : veb-sai. URL: http://passivehouseigua.com/passivehouse/passive-house-integrated-thermal-protection/ [in Ukrainian].

The purpose of the research is to create effective thermal insulation materials based on vegetable raw materials and to obtain lamellar heat-insulating material with good mechanical and biocidal properties based on natural plant material and plant waste.

Methodology. The main physical and mechanical properties of thermal insulation slabs (density, compressive strength at 10\% deformation) were determined in accordance with DSTU B B.2.7-38-95 "Materials and products of thermal insulation. Test methods ".

Results. Tests for strength at 10\% deformation were performed on samples of thermal insulation materials with a size of $100 \times 100 \times 100 \mathrm{~mm}$, changing the components and the amount of filler.The obtained data allow to establish that for all compositions the strength of samples from a mixture of moss and straw is greater than for samples of moss and reeds.

The cube samples made of a mixture of moss and reed have the same disadvantages as the slabs with a one-component filler: loose mossy fibrous structure, lack of coherent cane carcass, shrinkage deformation after drying.It is also important that with the same amount of binder, increasing the amount of crushed reeds or straw in the total weight of the aggregate leads to increased strength of the samples. It was found that for all compositions the strength of samples of moss and straw is greater than for samples of moss and reeds.Increasing the amount of aggregate and liquid glass of sodium leads to an increase in the density of insulating materials containing moss in 1.3 - 1.4 times, increase in compressive strength at 10\% deformation in 1.9 4.2 times.In order to eliminate the shortcomings of the material with a one-component filler reed or rye straw can be added into its composition. The presence of straw in the composition with moss increases the strength at 10\% deformation by 1.5-3 times, flexural strength by 2-3.2 times and eliminates shrinkage deformation with a slight increase in thermal conductivity.

Scientific novelty. The obtained results allow to create lamellar thermal insulation material with good physical and mechanical properties, which has biocidal properties based on natural plant material and crop waste.

Practical significance. Finding and creating effective thermal insulation materials based on cheap raw materials remains a challenge. The criterion of saving fuel and energy resources in the production of thermal insulation materials is of great importance. Depending on the composition of the substances from which thermal insulation materials are made, they can under certain conditions affect the insulated surfaces, the environment and the human or animal body.

Key words: insulation, moss, strength, raw materials, agricultural waste, reed straw.

Стаття рекомендована до друку доктором технічних наук, професором Луцьького національного технічного університету Байдаковою Л.І. Дата надходження в редакиію 17.12.2021 p. 